\title{
DOI: 10.52363/passa-2021.1-6
}

UDC: $351.777: 349.6$

Semiletov Oleksandr, researcher, National University of Civil Defence of Ukraine,

Kharkiv

ORCID: 0000-0002-7903-0098

\section{INITIATIVES AND PROPOSALS FOR IMPROVING THE ENVIRONMENTAL SITUATION}

The article considers public management approaches to ensuring the rational use of natural resources from the standpoint of analysis of foreign management practices in this area. The Index of ecological efficiency in our state is investigated. The ways to improve and influence the domestic policy and the characteristic features of the current legislation in the field of environmental protection, as well as the directions of its consideration in Ukraine are identified.

Key words: public administration, natural resources, European experience, modernization of legislation.

Formulation of the problem. The use of natural resources is an urgent task of any state and is becoming increasingly important due to the increasing impact of globalization and other external factors. Today, the use of these resources and their extraction includes not only the cost of production and the threat of depletion, but also the cost of restoring natural resources and their recycling. There is also the problem of depletion of natural resources. The world community is already facing pollution, clean water, air, land resources and others. All this determines the relevance of the chosen research topic.The purpose of the article is to generalize the foreign experience of public administration in the field of natural resources, as well as to identify the main tools for such management 
with a possible outline of approaches to the formation of domestic legislation in the field of public environmental management.

\section{Analysis of recent research and publications.}

The generation and use of household and industrial waste has been the object of study of the economics of nature management for several decades. The problem of modernization of the domestic waste management system has also become relevant in connection with the need to implement environmental directives of the European Union. A significant number of Ukrainian scientists consider one of the main prerequisites for efficient waste management to be the establishment of the recycling industry, which requires the formation of a modern institutional basis for diversification of investment sources of projects. However, the current practice of investment support for waste recycling shows that secondary resource use projects have not been properly disseminated, which leads to excessive waste accumulation, and this requires expanding the institutional corridor to attract domestic and foreign investment in waste management. The following domestic and foreign scientists and specialists were involved in ensuring the utilization of solid household appliances: I.L. Abalkina [7], VB Zhukovitsky [8], A.S. Greenin [9], N.B. Eskin [10], Yu. Batyr, O. Volkov, S. Dombrovska, O. Kryukov, N. Maevska, S. Maistro, A. Omarov, P. Rabinovych, Y. Salatyuk, V. Shevchuk and others. The definition of problems of public administration in the field of environmental protection was made in the works of foreign scientists I. Ansoff, O. Balatsky, A. Pechchei, D. Meadows, M. Mesarovich and others.

\section{Presenting main material}

During his speech at the All-Ukrainian Forum "Ukraine 30. Ecology", President Volodymyr Zelensky signed a decree on the launch of the "Green Country" project. "We are launching the Green Country project. I will say at once that this is not a political project, but a purely ecological one for nature and the environment. We have set ourselves an ambitious but, I am sure, achievable goal - to increase the area of forests by one million hectares in 10 years. For this purpose, in the next three years we strive to plant one billion trees in Ukraine, "Volodymyr Zelensky said during a speech at the forum. 
The head of state outlined the most important areas in the field of ecology and environmental protection. Thus, according to the President, over the past two years, changes have been introduced in the field of subsoil use, which has long been associated exclusively with corruption and illegal mining. In particular, by decision of the National Security and Defense Council, a full audit of all subsoil and their users, search and revocation of illegally obtained permits and so-called dormant licenses has begun.

The forum also raised issues related to industrial pollution. "The issue of the Chornobyl Exclusion Zone is no less important. At my initiative, the process of revitalization of the exclusion zone was started and the program of its development for the next three years was approved. It envisages changes in infrastructure, a new concept of territorial development, domestic and international promotion of Chernobyl. It should become a powerful magnet for tourists from Ukraine and around the world, and the exclusion zone should become a revival zone, "said the President of Ukraine." Together with international partners, we will contribute to the fight against it: the modernization of public infrastructure and industry, development of renewable energy sources, electric transport, energy efficiency "[11]. Analyzing the data and statistics of forest raw materials, it should be noted that the accounting of forest resources of the whole country was not conducted, the last census according to the forest cadastre took place on January 1, 2011. Therefore, weight should be given because the area of real "forested forests" and planned may differ significantly.

It should also be noted that according to the Forest Agency of Forest Resources of Ukraine from 2020. More than half of the country's forests are man-made and in need of intensive care. The age structure is dominated by medieval plantations, the share of mature and overripe plantations is $18.7 \%$. The average age of forests is over 60 years, and there is a gradual aging of forests, which leads to the deterioration of their sanitary condition. Forestry enterprises restore and create new forests on a total area of 40 thousand hectares. annually, which is insufficient given the dynamics of illegal logging and fires, according to the Forest Resources Agency of Ukraine, the area of fires amounted to 74,623 hectares. 
2,311 hectares of forest crops were written off, of which 621 hectares were prepared for reforestation.

Attention should also be paid to the material and technical condition of fixed assets of forestry enterprises because they are outdated and can be effective. Financing and logistical support of forestry tends to be self-financing, so the vehicle fleet is outdated and inefficient. According to the Minister of Ecology and Energy of Ukraine Roman Abramovsky, "Planting 1 billion trees within the Green Country project in the next three years will require UAH 2 billion, which will be attracted through forestry activities," said the Minister of Environment and Natural Resources of Ukraine.

Vice President of the Forestry Academy of Sciences of Ukraine, Professor of the Department of Ecological Economics of the National Forestry University of Ukraine Ihor Soloviy expressed his opinion on the current state of afforestation and reforestation in Ukraine. According to him, now the pace of planting and reforestation is far from what is needed to implement the ambitious plan of Zelensky.

"In 2020, 39.2 thousand hectares of forests were regenerated in Ukraine, and only 2.1 thousand hectares of new forests were created. To plant 1 million hectares in three years, it is necessary to increase forest planting by 150 times. The current pace is due to the lack of land for afforestation, which is distributed, privatized and reluctantly transferred for afforestation by private or municipal owners. Forestries are also not motivated to perform such work to a large extent. To implement the president's proposal, it is necessary to provide significant funding for the selection of plots for afforestation, compensation to owners, planting work and care for the established plantings "[2]. As Petro Peshko, Head of the Khmelnytsky Oblast Department of Forestry and Hunting, comments on the situation with forestry reform and its financial situation, "The most important thing today is to strengthen the material and technical base of forestry enterprises in Ukraine and significantly improve their financial condition. Therefore, one of the first steps in the reform should be changes in taxation, environmental legislation and other regulations foreign legal acts. This will provide an opportunity to accumulate finances and modernize the industry. 
These investments will pave the way for the purchase of modern machinery and mechanisms for forest care, improve production processes and more, as today's tax system washes away from forestry enterprises almost all working capital.

In order to obtain an effective model of state forest management and avoid possible risks, it is also necessary to develop a clear optimization mechanism, which is primarily needed for unprofitable and unprofitable forests in Ukraine. Reforming such enterprises provides greater opportunities in financial and technical support and saves significant public funds. The consolidation of forestry enterprises is a painful process, because it is about reducing people. Therefore, in the process of optimization, the priority should be to save jobs. At the same time, as the State Forestry Agency emphasizes, it is necessary to take seriously the formation and rejuvenation of the personnel potential of enterprises, and this is exactly what re-certification will be, which is a necessary step in the framework of the reform. "

Returning to the discussion of the decree of the President of Ukraine, the President of Ukraine decided:

1. Start in 2021 the implementation of the environmental initiative "Large-scale afforestation of Ukraine".

2. The Cabinet of Ministers of Ukraine:

1) to develop within two months and submit to the Verkhovna Rada of Ukraine a bill on improving the system of protection, protection and reproduction of forests, including self-seeding, stimulating afforestation, preservation and restoration of natural ecosystems;

2) to develop and approve the state target program "Large-scale afforestation of Ukraine", aimed at solving problematic issues of forest management, primarily regarding the protection, defense, use and reproduction of forests;

3) take measures in the prescribed manner to:

- forestry reform, including improvement of the management system of state forestry enterprises; 
- identification of self-afforested and suitable for forest creation land plots of state and communal forms of ownership for the purpose of their further use to achieve optimal forest cover of Ukraine;

- ensuring adequate funding in 2022 and beyond for forest protection, conservation, use and reproduction activities;

- introduction of mechanisms to attract investment for reforestation and afforestation.

3. The Cabinet of Ministers of Ukraine together with the regional, Kyiv city state administrations in the framework of the environmental initiative "Large-scale afforestation of Ukraine" to ensure:

- promoting the implementation of initiatives of public associations to participate in activities for the protection, conservation, reproduction of forests, involvement in such activities of the population, especially young people;

- organization of media, exhibition, other informational and educational activities aimed at forming the ecological worldview of the population, disseminating information about the need to preserve and reproduce forest resources, including through social advertising, encouraging citizens to practice in this area, announcing and coverage of measures for conservation and reproduction of forests. [3].

The experience of public administration and sciences that are closely related to public administration is developing rapidly, namely the economic and political course of our state aimed at European integration into the European Union, so our state is taking steps to stabilize and approximate legislation to established norms. public investment process, create and support business ideas, attract foreign investment and cooperation, create a transparent mechanism of public control and proposals, cooperation in education, use cooperation to strengthen contacts and mutual exchange of experience between all sectors of civil society in Ukraine and Member States EU.

The process of harmonization and adoption of international legislation in some areas is developing according to schedule, in some major legislative documents are still 
under development or harmonization, so the main obstacles that are currently the decentralization of power.

The current administrative and institutional infrastructure of public administration is largely centralized with duplication of functions at the regional and local levels, often leading to conflicts and irresponsibility. In most EU countries, ensuring the proper state of the environment is the prerogative of local authorities.

The dominant concept of management of central bodies is the prevention of environmental pollution, harmonization of interaction between society and the environment, ie not protective, but reproductive.

There is also the problem of training quality, professional, multifaceted, administrative staff. Analyzing the national level of a comprehensive environmental monitoring system - a system of observation, assessment and forecasting of the environment, which prevents a comprehensive vision and proper management of the industry, as well as the worst impact on the environment and sustainable development processes. After all, the main purpose of the monitoring system is to support management decisions. Referring to the strategy of the state environmental policy of Ukraine for the period up to 2030, the following existing problems are identified:

The root causes of Ukraine's environmental problems are: subordination of ecological priorities to economic expediency; failure to take into account the consequences for the environment in legislative and regulatory acts, in particular in the decisions of the Cabinet of Ministers of Ukraine and other executive bodies; the predominance of resource and energy-intensive industries in the structure of the economy with mostly negative impact on the environment, which is significantly exacerbated by unregulated legislation in the transition to market conditions;physical and moral depreciation of fixed assets in all sectors of the national economy; inefficient system of public administration in the field of environmental protection and regulation of the use of natural resources, in particular inconsistencies in the actions of central and local executive bodies and local governments, unsatisfactory state of the state environmental monitoring system; low level of understanding in society of the priorities of environmental protection 
and the benefits of balanced (sustainable) development, the imperfection of the system of environmental education and vocational education; unsatisfactory level of compliance with environmental legislation and environmental rights and responsibilities of citizens; unsatisfactory control over compliance with environmental legislation and failure to ensure the inevitability of liability for its violation; insufficient funding from state and local budgets for environmental measures, funding of such measures on a residual basis. In contrast to European countries, Ukraine has a very low level of processing and utilization of solid waste and a high rate of their burial in landfills. A significant part of the landfills is overloaded and does not meet environmental and sanitary standards. Therefore, it is important to create a system of technological lines for sorting secondary raw materials. Waste generated in the process of medical care, processing of raw materials of animal origin, pharmacological and cosmetic industries, which contain dangerous pathogenic and opportunistic microorganisms, as well as waste electrical and electronic equipment, pose a significant threat to the environment and human health.

Scientists believe that the main reason for the poor state of the environment is the imperfect legal framework, the lack of an effective system of accounting and reporting, monitoring system in the field of waste management.

To address the goals of state environmental policy, there are stages of development: The first includes the implementation of which is planned for 2025, it provides for the stabilization of the environmental situation by consolidating changes in the system of public administration, which occurred through reforms of public environmental management, and implementation of European environmental norms, standards and responsibilities, improving environmental accounting systems and control, introduction of financial and economic mechanisms to stimulate ecologically oriented structural transformations in the economy, introduction of mechanisms to stimulate enterprises to energy efficiency, introduction of e-government, dissemination of ecological knowledge, as well as raising ecological awareness, informatization of environmental protection and nature management at all levels; 
The second stage includes the implementation of which is planned for 2030. It involves achieving significant progress in improving the environment by balancing socioeconomic needs and objectives in the field of environmental protection, ensuring the development of environmentally effective partnerships between the state, business entities and the public, sustainable low-carbon development, which will be an additional stimulus to the socio-economic development of our state.

Researchers note that innovations, including environmental ones, help strengthen the competitiveness of companies, as there is a strong relationship between market activity and new environmental products. Product and technological innovations help to win and retain market share, increase profitability in these markets. When researching this problem, it is first necessary to clearly define the concept of "innovation". In our opinion, the most successful approach is the one proposed by B. Santo: innovation is a social, technical or economic process that through the practical use of ideas and inventions leads to the creation of the best products, technologies, if they can bring to market additional income. In turn, innovative products are products that have undergone significant changes (its technical characteristics and scope of use are significantly different from the technical characteristics and scope of use of previously manufactured products), or newly introduced (fundamentally new) products [1]. Environmental technology is a fast-growing industry around the world. Becoming an increasingly important economic factor, environmental technologies face the task of innovative development on an industrial scale. The main markets for ecologically innovative goods are: - energy production and storage; - energy saving; - economical use of raw materials; - environmental friendliness of transport; - rational use of water resources - bioplastics and polymers; - solar cooling. Today, the segment of the world market of environmental technologies is about 1000 billion euros a year, being already an important factor in the development of the world economy. $45 \%$ of this segment is occupied by technological solutions in the field of energy saving. The economic growth of the environmental technology market segment is about $5.4 \%$ per year and experts estimate that it will amount to more than 2,200 billion euros per year [6]. 
It should also be noted that the leadership of most countries began to improve and monitor environmental developments and technical development, namely our country has taken as a basis the decision of the European community to reduce the use of cars with internal combustion engines and abandon them by 2040 .

It should also be emphasized that the following countries are leaders: France, Great Britain, Norway, the Netherlands, India, China, Germany are countries that seek to completely abandon internal combustion engines. So one of the steps in the domestic policy of the People's Democratic Republic of China is that North Korea is a leader not only in Asia but worldwide sales of electric vehicles in absolute terms. Last year, 351,000 new electric cars were sold in China. This is more than in all EU and US countries combined. On the doom According to experts, Beijing will announce the terms of a total ban on the sale of new gasoline and diesel cars in the near future.

So the City authorities are trying to force their residents to give up personal vehicles or change to environmentally friendly cars. The immediate motivation of the authorities is obvious: citizens need air to be healthier and cleaner, and traffic jams to be fewer. "As part of the National Transport Strategy until 2030, Ukraine plans to completely replace all urban public transport with electric and create the appropriate infrastructure for this," said Minister of Infrastructure Vladislav Krykliy recently. But it should be noted that the introduction of electric public transport is not very lively because it takes time to create an extensive infrastructure to meet the electric transport industry and growing public needs and significant financial resources.

Thus, one of the projects of the leadership of our state was a project to ban public transport with internal combustion engines. Also relevant is the problem of sorting and recycling of waste, namely. In our state of Ukraine there is a catastrophic situation in the field of household waste management. The current practice of household waste management in Ukraine is focused on the removal and disposal of household waste in landfills and landfills, most of which do not meet environmental safety requirements. Recycling plants work only on $40 \%$ power. Improper work on certification and reclamation of landfills. 
A popular way of waste management since Soviet times and 30 years ago is the removal and disposal of landfills and dumps, while waste disposal remains the cheapest of all types of solid waste management, which does not create incentives for businesses and local authorities to their processing. Approximately 13 million tons of solid household waste (MSW) are generated annually in Ukraine. It is analytically proved that the amount of waste per capita is three hundred kilograms and tends to increase. By nature, waste is classified as: food waste, paper and cardboard, secondary polymers, glass, metals, textiles, construction waste.

Nine million tons of paper, one and a half million tons of metals, two million tons of polymeric materials, and twenty million tons of food waste are lost annually at landfills. Due to the improper system of solid waste management in Ukraine, more than thirty thousand unauthorized landfills are created annually, the existence of which can be explained by "economic feasibility" - companies engaged in garbage removal are cheaper to take to an unofficial landfill, paying significantly less for state burial.

The landfill tax rate in Ukraine is about 0.30 euros / ton, while in the Netherlands 120 euros / ton, Belgium - 100 euros / ton, Finland - 90 euros / ton, Denmark - 80 euros / ton, the UK - 70 EUR / t, Sweden - 60 EUR / t.

According to the requirements of the Association Agreement with the EU, Ukraine must implement Directive № 2008/98 / EU on waste, according to which it is obliged to achieve by 2030 a recycling rate of $50 \%$ of waste through separate collection.

The average tariff for household waste management in Ukraine (population and industrial consumers) is about UAH 120.6 / m3, including UAH 37.86 / m3 for landfills. As a result, low tariffs for waste disposal services do not create incentives for businesses and local governments to recycle waste. Waste disposal in Ukraine remains the cheapest of all types of solid waste management, and the costs associated with the future closure of landfills and their reclamation are not included in the tariff for waste disposal.

Critically low level of solid waste processing. Due to the lack of a separate collection system and the imperfection of economic mechanisms to stimulate the use of waste as a secondary raw material in Ukraine, millions of tons of resource-rich materials contained in waste are lost every year. 
In Ukraine, the problem of household waste disposal remains unresolved - the existing waste incineration plants in Kyiv and Kharkiv do not meet modern environmental requirements and need to be reconstructed. At the same time, there are unsystematic isolated attempts in some cities to build recycling plants to obtain RDF fuel, which can hypothetically be used in cement plants. However, Ukraine has not yet regulated the use of solid waste fuel (RDF) as a potential energy source. Cement plants in Ukraine do not demand such fuel due to its probable low quality (garbage is not sorted). And private investors are not interested in investing in energy recovery plants, as there are no incentives or guarantees. In most developed countries, the policy of solid waste management is aimed at curbing the volume of their production and increasing the depth of processing. Thus, in the EU countries, solid waste management is based on the construction of the most environmentally friendly system for handling solid waste flows. In Denmark, Sweden, Belgium, the Netherlands, Germany, and Austria, less than 5\% of municipal solid waste is landfilled, and $35 \%$ is recycled; $15 \%$ goes to composting and biogas production, and $50 \%$ of municipal solid waste remains in most developed countries for incineration.

Incinerators are widely used in countries with high population densities (Sweden, Germany, Japan, Switzerland, Belgium, etc.). However, the operation of these plants in comparison with waste processing plants and landfills requires much higher capital and operating costs. Especially a significant part of the cost goes to filters that clean air emissions and make them safe for the environment. Such plants are expensive investments.

The largest number of incinerators is in Sweden. They provide 810 thousand homes with heat and 250 thousand homes with electricity. Sweden recycles more than $99 \%$ of its waste. The priority is not waste disposal at landfills, but segregation and processing. The Swedes collect newspapers, plastic, metal, glass, electrical appliances, light bulbs and batteries separately, and throw food waste in separate bags. Most solid waste is processed, used or fertilized. Newspapers are turned into paper pulp, bottles are reused or remelted into new elements, plastic containers become plastic raw materials; food is composted and becomes fertilizer or biogas. Sewage is treated to such an extent that it can be drunk. 
Special trucks travel through cities and pick up electronics and hazardous waste, chemicals. Pharmacists take the remnants of drugs. Non-segregated waste enters incinerators, where it is disposed of by incineration to produce heat for homes. The ash is sorted and sent for recycling.

Most of the non-segregated waste is incinerated in Germany (the energy obtained comes from the power plant). In a typical German yard or house, you can find at least 5 colorful garbage containers. Black - for unsorted waste, brown - for organic waste, blue for paper, yellow - for packaging and plastic, green - for colored glass, green with a white stripe - for colorless.

In EU countries, there is a two-rate tariff: for segregated waste - lower, for undivided higher (sometimes twice).

Scientists advise to improve the system of solid waste disposal by one of two options for its actual centralization:

a) under the direction of regional and district state administrations;

b) subordination to local self-government bodies (urban and rural territorial communities). The system of garbage collection, removal and utilization will be organized and controlled by the relevant authorities (state or local self-government) centrally, functioning on the basis of plans that will determine the volume and schedules of garbage collection and transportation from each facility, mode of operation of transport companies and waste sorting, waste processing, waste incineration plants, their production facilities, solid waste supply, etc.

To streamline the system of solid waste utilization by applying economic methods to increase its efficiency.First of all, it involves increasing the cost of waste disposal with the establishment of different tariffs for separated and undivided garbage, establishing a mechanism of interaction between apartment owners and private houses, apartment buildings, local governments, carriers, landfills, private investors willing to invest in construction waste sorting (waste processing, waste incineration) enterprises, by defining the rights and responsibilities of each and establishing an effective system of control over the fulfillment of obligations. Liberalization of the solid waste market 
This scenario provides maximum freedom in choosing the forms, methods and mechanisms of interaction. In this case, the relevant state and local authorities will only impose legal restrictions on market participants (both for residents and for companiescarriers and landfills, waste sorting (waste processing, incineration) enterprises). Restrictions will concern the protection of economic competition and private property, the prevention of environmental pollution, and financial discipline. All other aspects of the functioning of the waste market will be decided on a contractual basis.

It would be rational to decide to draw on the experience of European countries to increase the tax on unsorted garbage to introduce a model of extended liability of producers of goods for processing and disposal of their products after consumption. and use them at its discretion. Give preference to private investors in the construction of waste sorting (waste processing, incineration) plants; at the legislative level to establish a clear system of environmental requirements for waste processing enterprises; provide local authorities with the opportunity to enter into long-term agreements with the winners of tenders for solid waste processing, during which they will be able to guarantee the supply of solid waste and the payment of processing tariffs, if antitrust law is not violated, etc. to legally ensure the process of inventory of all landfills and landfills, to introduce an algorithm for transferring unauthorized landfills to the mode of legal operation, to oblige the relevant regulatory authorities to publish the results of monitoring; legislate certain functions of the police and the municipal guard to prevent improper handling of garbage and provide for their authority to impose sanctions in case of violations; strengthen administrative responsibility in the field of solid waste management. raw material processing makes it possible to push them into new ideas and projects.

One such project is the abandonment of plastic bags and the use of environmentally friendly components in the production, namely the production of machinery, cars, roads, communications, and other industries.

Conclusions: summing up we can say that our country is developing rapidly, new approaches and ideas for the development of domestic and foreign policy, contribute to its formation as an independent competitive state: it is the policy of the president and his team helped create a new direction for society. The world community is experiencing turbulent times when all countries are developing rapidly and building new approaches to 
life when creating conditions for waste-free production, fragile coexistence with nature, improving the ecological situation in our country, through rational and balanced waste management.

\section{Reference}

1. The Head of State launched the Green Country project aimed at protecting nature and the environment in Ukraine [Electronic resource] / Official Internet Representation of the President of Ukraine - Kyiv: Creative Commons Attribution 4.0 International. - Access mode: https://www.president.gov.ua/news/glava-derzhavi-dav-start-proektu-zelena-krayina-spryamovanom$68865-$

2. DECREE OF THE PRESIDENT OF UKRAINE №228 / 2021 On some measures to preserve and restore forests [Electronic resource] / Official Internet Representation of the President of Ukraine Kyiv: Creative Commons Attribution 4.0 International. - Access mode https://www.president.gov.ua/documents/2282021-39089

3. Martynenko VO Experience of EU countries on modern mechanisms of environmental management in Ukraine. URL: http: // dspace. uabs.edu.ua/bitstream/ 123456789/896/1 / 5.pdf

4. Pomaza-Ponomarenko A., Medvedeva D. Methodology of monitoring and evaluation of the effectiveness of state policy in the field of environmental safety in Ukraine. URL: https://ejss.nuczu.edu.ua/index.php/ejss/article/view/55.

5. Rotar A.V. Innovative processes in industry: their economic content and essence / Rotar AV // Statistics of Ukraine. - 2007. - №1. - P. 37-40.

6. Environmental policy innovations and values from the point of view of the company. - Berlin: Umweltbundesamt, 2007. - $257 \mathrm{p}$

7. Abalkina IL Problems of urban and industrial waste management in the United States: an overview. Ecology and problems of the big city. M .: RAN INION, 1992. S. 27-49

8. Жуховицкий В.Б. Utilization of solid household waste / V.В. Жуховицкий, В.Я. Meller, A.N. Tugov. Dnepropetrovsk: "Svidler AL", 2011. 546 p.

9. Grinin AS Industrial and household waste: storage, utilization, processing / A.S. Гринин, B.Н. Новиков. М .: FAIR-Press, 2002. 336 s. 5. Yufit S. Typical mistakes of authors of projects of incinerators. City administration. 2000. № 5. S. 68-71.

10. Eskin NB Development and analysis of various technologies for burning household waste / N.B. Eskin, A.N. Tugov, MA, Izyumov. Development of technologies for preparation and combustion of fuel at power plants: Sat. scientific Art. M .: VTI, 1996. S. 77-84

11. "Green Country" - how realistic is Zelensky's new initiative? [Electronic resource] / - Access mode: https://parlament.org.ua/2021/06/09/zelena-krayina-naskilki-realistichna-nova-initsiativazelenskogo/. 